\title{
PENCEGAHAN DAN PEMBERANTASAN TINDAK PIDANA PENCUCIAN UANG
}

\author{
Herlina Hanum Harahap \\ Universitas Muslim Nusantara Al Washliyah \\ Linahrp4@gmail.com
}

\begin{abstract}
ABSTRAK
Pencegahan adalah proses, cara, tindakan mencegah atau tindakan menahan agar suatu tidak terjadi. Dapat dikatakan suatu upaya yang dilakukan sebelum terjadinya pelanggaran Pemberantasan adalah proses atau cara memberantas tindak pidana pencucian uang agar tidak terjadi tindak pidana yang akan mengakibatkan Negara rugi.Pencucian uang adalah suatu proses atau perbuatan yang bertujuan untuk menyembunyikan atau menyamarkan asal usul uang harta kekayaan yang diperoleh dari hasil tindak pidana yang kemudian diubah menjadi harta kekayaan yang seolah-olah berasal dari kegiatan yang sah. Dengan demikian tidak mengherankan apabila bentuk kejahatan yang semula bersifat sederhana berubah menjadi kejahatan yang bersifat lebih maju sesuai dengan tingkat kemajuan teknologi dan ilmu pengetahuan. Sehingga kejahatan yang demikian sulit dirumuskan norma hukum penanggulangannya, dan hukum pidana sendiri agak sulit menjangkaunya contohnya kejahatan yang demikian itu adalah korupsi yang menggunakan alat-alat canggih seperti telepon dan komputer serta kejahatan tersebut terjadi di dalam suatu lembaga perbankan. Umumnya para pelakunya adalah pengurus bank itu sendiri ataupun dengan bekerja sama dengan pihak lain yang bukan oknum bank itu sehingga orang lain ataupun orang awam tidak mengetahuinya atau sulit memahaminya.
\end{abstract}

Kata kunci : Pencegahan,Pemberantasan, Tindak Pidana dan Pencucian Uang.

\begin{abstract}
Prevention is a process, means, action to prevent or action to prevent something from happening. It can be said that an attempt is made before the occurrence of an offense. Eradication is a process or method of eradicating the crime of money laundering so that no crime will result in losses to the State. Money laundering is a process or act that aims to conceal or disguise the origin of the acquired assets. from the proceeds of a criminal act which are then converted into assets as if they originated from legitimate activities. Thus, it is not surprising that the form of crime which was originally simple turns into more advanced crime by the level of technological and scientific advancement. So that such crimes are difficult to formulate legal norms to deal with them, and criminal law itself is rather difficult to reach. For example, such crimes are corruption that uses sophisticated equipment such as telephones and computers and these crimes occur within a banking institution. In general, the perpetrators are the bank managers themselves or in cooperation with other parties who are not members of the bank so that other people or ordinary people do not know about it or have difficulty understanding it.
\end{abstract}

Keywords: Prevention, eradication, Crime, and Money Laundering.

1. PENDAHULUAN

Mencegah dan memberantas tindak pidana pencucian uang termasuk berbagai tindak pidana yang menghasilkan harta kekayaan yang tidak sah maka berdasarkan Undang-Undang tersebut telah dibentuk Pusat Pelaporan dan Analisis Transaksi Keuangan yang tugas pokoknya adalah membantu penegakan hukum dalam mencegah dan memberantas tindak pidana pencucian uang dan tindak pidana berat lainnya dengan cara menyediakan informasi intelijen yang dihasilkan dari analisis terhadap laporan-laporan yang disampaikan kepada PPATK untuk melaksanakan tugas pokok tersebut PPATK berkewajiban antara lain membuat pedoman bagi penyedia jasa keuangan (PJK) dalam mendeteksi perilaku pengguna jasa keuangan yang 
melakukan transaksi keuangan mencurigakan.

Oleh karena itu sudah semestinya kalau pemerintah dan seluruh lapisan masyarakat menaruh perhatian besar terhadap masalah penanganan tindak pidana pencucian uang tersebut. Salah satu bentuk nyata dari kepedulian Indonesia terhadap tindak pidana pencucian uang adalah dengan di sahkannya Undang-Undang Nomor 8 Tahun 2010 tentang tindak pidana pencucian uang dengan Undang-Undang ini pencucian uang resmi dinyatakan sebagai tindak pidana dan oleh karenanya harus dicegah dan diberantas.

\section{Tindak Pidana Pencucian (Money Laundering)}

Money Laundering menurut Sarah N. Welling, dimulai dengan adanya "uang haram" atau "uang kotor" (dirty money). Uang dapat menjadi kotor dengan adanya dua cara, pertama, melalui pengelakan pajak (tax evasion). Yang dimaksud dengan "pengelakan pajak" ialah memperoleh uang secara legal, tetapi jumlah yang dilaporkan kepada pemerintah untuk keperluan penghitung pajak lebih sedikit dari pada yang sebenarnya diperoleh. Kedua, memperoleh uang melalui cara-cara yang melanggar hukum. Teknik-teknik yang biasa dilakukan untuk hal itu, antara lain penjualan obat-obatan terlarang atau perdagangan narkoba secara gelap (drug sales atau drug trafficking), penjualan gelap (illegal gambling), penyuapan (bribery), terorisme (terrorism), penyelundupan minuman keras, tembakau dan pornografi (smuggling of contraband alcohol, tembacco, pornography), dan kejahatan kerah putih (White collar crime). Praktek-praktek Money laundering memang mula-mula dilakukan hanya terhadap uang yang diperoleh dari lalu lintas perdagangan narkotika dan obat-obatan sejenis itu (narkoba atau drug) atau yang dikenal sebagai illegal drug trafficking. Namun demikian, Money laundering dilakukan pula terhadap uang-uang yang diperoleh dari sumber-sumber kejahatan lain seperti yang di kemukakan diatas.

\section{Perkembangan Pengaturan Tindak Pidana Pencucian Uang Di Indonesia}

Sebagaimana telah disinggung di atas bahwa dalam sistem penegakan hukum, rezim anti pencucian uang hadir dengan paradigma baru, semula orientasi tindak pidana pada umumnya adalah mengejar pelaku pidana, sedangkan pada masa sekarang orientasinya adalah lebih mengejar pada hasil tindak pidananya. Mengingat tindak pidana pencucian uang termasuk transnational organize crime, dan melibatkan harta kekayaan pada umumnya dalam jumlah besar, untuk efektifitas pencegahan dan pemberantasannya diperlukan koordinasi bukan hanya dalam tingkat nasional tetapi juga internasional, serta kemudahan tersebut telah diberikan dalam undangundang pencucian uang antara lain secara khusus diatur mengenai pengecualian dari ketentuan rahasia bank dan kerahasiaan transaksi keuangan lainnya, azas pembuktian terbalik, serta penyitaan dan perampasan aset. Sehubungan dengan itu, maka pada tanggal 17 April 2002 pemerintah mengundang-undangkan Nomor 15 Tahun 2002 tentang Tindak Pidana Pencucian uang (UU-TPPU) yang pada pokoknya mengatur hal-hal sebagai berikut:

a. Mengatakan secara tegas, bahwa pencucian uang adalah suatu tindak pidana 
b. Mendirikan Pusat Pelaporan dan Analisis Transaksi Keuangan (PPATK) sebagai Focal Point dalam upaya pencegahan dan pemberantasan Tindak Pidana Pencucian Uang

c. Kewajiban menyampaikan Laporan Transaksi Keuangan Mencurigakan (LTKM) dan Laporan Transaksi Keuangan Tunai (LTKT) oleh penyedia jasa keuangan kepada PPATK

d. Adanya proteksi bagi bank dalam menyampaikan laporannya dikecualikan dari ketentuan rahasia bank. Penyediaan jasa keuangan tidak dapat dituntut secara perdata dan pidana sehubungan dengan laporan yang disampaikan.

\section{METODE PELAKSANAAN}

1. Metode pelaksanaan kegiatan Menjelaskan tahapan-tahapan dan langkah-langkah dalam melaksanakan kegiatan dan solusi yang ditawarkan untuk mengatasi permasalahan. Metode yang digunakan dalam kegiatan ini adalah diawali dengan metode ceramah, selanjutnya berdiskusi dengan para peserta, dan Tanya jawab tentang permasalahan yang berkaitan dengan tindak pidana pencucian uang. Pada penyuluhan ini peserta pengabdian masyarakat juga diberikan materi bagaimana cara/tehnik untuk memahami tentang pencagahan dan pemberantasan tindak pidana pencucian uang. Kesemua metode tersebut diterapkan bersama-sama dalam acara penyuluhan ini yang ditentukan oleh panitia pengabdian masyarakat.

2. Metode pendekatan
Metode disini merupakan metode pendekatan yang ditawarkan untuk menyelesaikan permasalahan yang disepakati

Ada tiga metode pendekatan yang ditawarkan dalam untuk menyelesaikan permasalahan yang dihadapi Desa sebagai mitra ini yaitu:

a. Sosialisasi dengan ceramah

Salah satu metode yang disampaikan dalam kegiatan PKM berupa penyuluhan ini adalah dengan metode ceramah seperti tampak yang terlihat dalam gambar tersebut, dalam hal ini ketua tim abdimas sedang menyampaikan materi pengabdian yang berlokasi di kantor kepala Desa.

b. Diskusi

Selanjutnya metode yang kedua dalam pelaksanaan kegiatan PKM ini adalah dengan menggunakan metode "diskusi" agar peserta abdimas juga lebih aktif dan paham terhadap materi yang disampaikan tersebut, misalnya dapat dilihat dalam gambar berikut:

C. dan Tanya jawab

Selanjutnya diberi kesempatan kepada peserta abdimas untuk bertanya tentang materi yang disampaikan terkait dengan pelaksanaan pencegahan pemberantasan tindak pidana pencucian uang sehingga para peserta abdimas ini bisa paham dan mengerti terhadap apa yang disampaikan dalam kegiatan PKM ini.

\section{HASIL DAN PEMBAHASAN}

\section{Tahap-Tahap Tindak Pidana Pencucian Uang}

1. Tahap Penempatan Dana (Placement)

Dalam tahap penempatan ini, uang hasil kejahatan ditempatkan pada bank tertentu yang dianggap aman. Penempatan uang ini 
dimaksudkan untuk sementara waktu, dalam tahap ini juga dilakukan proses membenamkan uang tersebut dengan cara

a. uang tersebut dibenamkan dengan proses lembaga keuangan, misalnya melalui rekening Koran, surat berharga, traveler's cheque, dan sebagainya;

b. sebanyak mungkin melakukan transaksi tunai (cash and carry) sehingga asal usul uang tersebut menjadi semakin sulit dilacak.

2. Tahap Pelapisan (Layering)

Dalam tahap ini dilakukan kegiatan-kegiatan yang bertujuan untuk meghilangkan jejak atau indikasi dari asal usul uang tersebut. Dalam tahap ini uang benar-benar dicuci atau diputihkan, antara lain melalui pembelian saham di Bursa Efek, transfer uang ke negara lain dalam bentuk mata uang asing, meminjam uang di bank lain dengan menggunakan deposito yang ada di bank, membeli property tertentu, membeli valuta asing, transaksi derivative, dan lain-lain.

3. Tahap Integrasi

Integrasi adalah upaya menggunakan harta kekayaan yang telah tampak sah, baik untuk dinikmati langsung, diinvestasikan ke dalam berbagai bentuk kekayaan material maupun keuangan, diperlukan untuk membiayai kegiatan bisnis yang sah, ataupun untuk membiayai kembali kegiatan tindak pidana. Dalam melakukan pencucian uang, pelaku tidak perlu mempertimbangkan hasil yang akan diperoleh dan besarnya biaya yang harus dikeluarkan, karena tujuan utamanya adalah untuk menyamarkan atau menghilangkan asal usul uang sehingga hasil akhirnya dapat menikmati atau digunakan secara aman.

\section{Pencegahan Dan Pemberantasan Tindak Pidana Pencucian Uang}

Upaya pencegahan dan
pemberantasan pencucian uang di
Indonesia dimulai pada tanggal 17 April
2002 yaitu saat diberlakukannya UndangUndang No. 15 Tahun 2002 tentang tindak pidana pencucian uang. Tahapan pencegahan pencucian uang sudah dilakukan sebelum Undang-Undang tersebut lahir namun lingkupnya hanya terbatas pada bank. Hal ini dapat ditunjukkan melalui seperangkat regulasi yang dikeluarkan oleh otoritas perbankan yang lebih dikenal dengan Peraturan Bank Indonesia tentang Prinsip Mengenal Nasabah.

Pengaturan ini, tentu didasari oleh alasan yang kuat terutama mengenai dampak yang ditimbulkan oleh kegiatan pencucian uang dalam perekonomian dan untuk memenuhi prinsip-prinsip pengawasan bank secara efektif sesuai standar internasional. bidang ekonomi pencucian uang dapat: merongrong sektor swasta yang sah karena biasanya pencucian uang dilakukan dengan menggunakan perusahaan-perusahaan (front cmpanies) untuk mencampur uang haram dengan uang sah sehingga bisnis yang sah kalah bersaing dengan perusahaan-perusahaan.

Melaksanakan mekanisme pencegahannya harus benar-benar meneliti dan memantau nasabahnya. 
Apabila menyimpang dari profil dan karakteristik nasabahnya maka bank segera harus mencurigai transaksi tersebut dan melaporkannya ke PPATK agar tidak terjadi tindak pidana di bank tersebut. Selain bank para karyawan Bank pun harus bekerjasama untuk mencegah terjadinya tindak pidana pencucian uang. Dalam melaksanakan tahap-tahap pencegahan tindak pidana dan dalam transaksi terdapat salah satu transaksi yang mencurigakan seperti yang terdapat dalam Pasal 1 ayat (5) Undang-Undang No. 8 Tahun 2010 maka bank harus segera menolak transaksi tersebut.

\section{KESIMPULAN}

Pencegahan dan pemberantasan Tindak pidana pencucian uang dengan melaksanakan atau menjalankan tahaptahap dalam sistem pencegahan dan pemberantasan tindak pidana pencucian uang, seperti tahap pengenalan nasabah, pemantauan terhadap transaksi mencurigakan dan pelaporan kepada PPATK. Bank sering menjadi sarana dalam tindak pidana pencucian uang Bank berperan sebagai pihak pelapor dalam pencegahan tindak pidana pencucian uang sedangkan yang berhak melakukan pemberantasan tindak pidana pencucian uang adalah pihak PPATK.

Pencegahan dan pemberantasan tindak pidana pencucian uang, apabila tranransaksi mencurigakan di Bank pertama pihak bank akan melaporkannya agar tidak terjadi tindak pidana pencucian uang. Dalam melaksanakan mekanismenya Bank telah menjalankan mekanisme sesuai dengan prosedur yang terdapat didalam peraturan perundangundangan yang berlaku. pelaporan transaksi keuangan mencurigakan yang dilakukan dengan 2 (dua) cara : apabila transaksi keuangan mencurigakan sistem pelaporan menggunakan cara sistem online dengan aplikasi yang menggunakan cara (GRIPS), dan transaksi tunai, sistem pelaporan yang digunakan Bank adalah sistem pelaporan secara manual yaitu mengirim surat ke PPATK.

\section{REFERENSI}

Bambang lopa \& moch yamin, Undangundang pemberantasan korupsi, Alumni, Bandung, 2001.

Bismar Nasution, Rezim Anti-Money Laundering Di Indonesia, Books Terrace \& Library, Bandung, 2008.

Munir Fuady, Hukum Perbankan Modern Buku Kedua (Tingkat Advance), PT. Citra Aditya Bakti, Bandung, 2001.

Neni Sri Imaniyati, Pengantar Hukum Perbankan Indonesia, Refika Aditama, Bandung, 2010. 